industrial accidents ending fatally which were reported to the Factory Department during 1906 in pursuance of the provisions of the Factory and Workshops Act, 1901. The total number of fatal accidents in the United Kingdom in 1905 was 1063 and in 1906 1116. Of these the construction of buildings contributed 145 (all males) in 1906, against 117 in 1905 ; the docks 143 (all males) in 1906, against 142 in 1905; locomotives 112 (all nales), against 109; foundries 118 (one female), against 125 ; and ship-building 110 (all males), against 108 in the previous year. The total number of fatal accidents comprised 1098 males and 18 females. In regard to industrial poisoning, lead working was responsible for 632 attacks in 1906, against 592 in 1905; mercury for four cases in 1906, against eight in 1905; arsenic for five cases in 1906, against one case in 1905 ; and anthrax for 66 cases in 1906, against 59 in the previous year. There were altogether 707 cases reported of industrial poisoning in 1906, while in 1905 the total number was 663 .

ON Saturday, March 2nd, a sessional meeting of the Royal Sanitary Institute will be held at the Parkes Museum, when a discussion will take place on the Bacterial Treatment of Sewage, with special reference to the Biolysis of Organic Nitrogen, to be opened by Mr. W. D. Scott-Moncrieff. The chair will be taken at 11 A.M. by Dr. J. Lane Notter, chairman of the council of the institute. At 1 P.M. there will be an adjournment for luncheon. In the afternoon a visit will be made to the Staines sewage outfall works at Ashford. The train will leave Waterloo Station for Ashford at 2.10 P.M. Those wishing to attend the inspection and requiring accommodation in the brakes from Ashford to the works should notify the secretary of the institute not later than Feb. 26th.

A BILL "to make further provision with respect to the manufacture, importation, and sale of butter and margarine and similar substances" has been presented by Sir Edward Strachey and was ordered by the House of Commons to be printed on Feb. 14th. The clauses inter alia relate to the inspection of factories, limits of moisture, regulations as to curd, the sale of butter mixtures, imitation butters, and penalties for offences. We shall deal with this matter in a future number.

ON Feb. 14th a meeting of the Russian Physico-Chemical Society was held at the University of St. Petersburg to consider the perpetuation of the memory of the late deceased Professors Mendeléeff and Menschutkin, the latter having been president of the society. The Novoe Tremya announces that biographies of both distinguished men will be prepared and that a fund open to contributions from the whole world will be raised with the object of erecting a monument to Professor Mendeléeff in front of the University building.

Sir William Hingston, whose death is announced as having occurred at Ottawa on Tuesday, Feb. 19th, was one of the best known public men in Canada. He was a distinguished surgeon, an ex-mayor of Montreal, and a Senator of the Dominion.

THE annual general meeting of the Association of Certificated Dispensers will be held in the Apothecaries' Hall, London, on Thursday, Feb. 28th, at 7.30 P.M., when an address will be delivered by Dr. F. S. Toogood.

A LECTURE will be delivered at the Royal Sanitary Institute, Parkes Museum, by Professor Ronald Ross, F.R.S., on "Points of Interest Connected with Tropical Sanitation," on Friday, March 1st, at 5.30 P.M.

THE death is announced at Maidstone last week of Dr. James Edmund Huxley, the brother of Professor Huxley.
Dr. Huxley was formerly superintendent of the Kent County Lunatic Asylum and was 87 years of age.

Dr. A. J. Rice Oxley has been appointed a Physician-inOrdinary to Her Royal Highness Princess Henry of Battenberg.

\section{THE OBSTETRICAL SOCIETY OF LONDON AND ITS EXAMINATIONS FOR MIDWIVES :}

A CHAPTER IN THE HISTORY OF THE MIDWIVES QUESTION.

\section{By Charles J. Cullingworth, M.D. Durh., F.R.C.P. LOND,}

CONSULTING OBSTETRIC PHYSICIAN, ST. THOMAS'S HOSPITAL.

"SEVERAL young physicians in my department of practice have been endeavouring to start an obstetrical society-Dr. Tyler Smith, Dr. Graily Hewitt, Dr. Priestley, \&c.

They have requested me to become President and this evening our first meeting took place at the Freemasons' Tavern to pass a series of resolutions and inaugurate the society." So writes in his diary " Dr. Edward Rigby (the second) under date Dec. 16th, 1858. He goes on to speak of what happened at the meeting and to express his private opinion of one or two of the speakers as well as of Sir Henry Halford and the Royal College of Physicians of London, but for whose illiberal opposition, he says, there would have been an Obstetrical Society of London long before. My object, however, in this paper is not to relate the history of the Obstetrical Society, but, now that the passing of the Midwives Act has rendered it unnecessary for the society to continue its voluntary examinations, to trace, in somewhat greater detail than has hitherto been attempted, the various occurrences that led the society to become actively interested in the midwives question and to place on record the manner in which that interest has from time to time been manifested. Having therefore glanced for a moment at the círcumstances attending the society's birth, and introduced to my readers its founders and first president, I pass on to my more immediate task.

It is a matter of common knowledge that the institution by the Obstetrical Society of London of a voluntary examination of midwives was indirectly due to a suggestion made by the late Dr. W. Farr, superintendent of the statistical department in the office of the Registrar-General, but I am not aware that Dr. Farr's letter containing this fruitful suggestion has ever been published. As it has become of some historic interest $I$ give it here in full. It is addressed to the then President of the society, Dr. Robert Barnes, and is as follows :-

General Register Office, Somerset House, December 20th, 1866 .

MY DEAR DR. BARNES, - I wrote a paper on the mortality of children (in the States of Europe) under 5 years of age for the London Statistical Society, and got some good information about the management of children from Austria, France, \&c. In Italy they have appointed a committee to report cn the subject.

Now I want your Society to undertake to give us an account of the Now I want your Society to undertake to give us an account of the
treatment of children in London and the several parts of England; and, if it would kindly consent to do so, we should be sure that it would be
done well. I enclose a list of queries which were answered for Scotland by Dr. Starkie (\%).

The treatment of children differs of course in the manufacturing districts where the women are employed in mills from the treatment in agricultural parishes and in country towns. But besides this, there are local differences in the North and South-in Norfolk and in Wales, for example.

This subject is of great importance, and it appears to be the first step towards determining the causes of the great differences in the mortality of children.

If you will kindly undertake to bring the matter before the Council of the Onstetrical Society, and also inform me of their decision, I shall
feel greatly obliged. I am, my dear Dr. Barnes, Your very faithful servant,

1 This diary has never been published. I was kindly allowed to see it some little time ago by its present possessor, a member of Dr. Kigby's family. who very courteously gave me leave to make a few extracts from it.

2 Summaries of the various practical steps taken by the Society to further the better training and education of midwives have been drawn up from time to time and published. See for example vol. Xxxiii. of the Transactions for 1891, p. 59 ; Dr. F. H. Champneys's inaugural address as president of the society (see Transactions of the Obstetrical Society of London, vol. xxxvii. for 1895, pp. 94 et seq.); wards reprinted); and a pamphlet by Dr. Amand Routh, dated wards repr 
The connexion between this letter and the institution of an examination for midwives may not at first sight seem very obvious. It will be my business in what follows to show how the one gradually led to the other. The letter was read at a council meeting on Jan. 2nd, 1867, and Dr. Barnes, in referring to it in his presidential address at the annual meeting of the society held the same evening, expressed his gratification that the aid of the society had been "sought in a work of such great national and human interest," and announced that the council had resolved to undertake the proposed investigation. ${ }^{3}$ Accordingly, when the new council met in February a committee was appointed, consisting of the President (Dr. J. Hall Davis), Dr. Tyler Smith, Dr. Barnes, Dr. Graily Hewitt, Mr. Ourgenven, and the honarary secretaries (Dr. Murray and Dr. Gervis), to carry out Dr. Farr's suggestion. The committee was not able to set to work at once, but eventually a series of questions was drawn up and printed and a copy sent to every Fellow of the society. A large number of answers was received and on June 2nd, 1869, the committee presented to the society a first instalment of its report, consisting of an analysis of the various replies that had been sent in prepared by one of the honorary secretaries, Dr. Gervis. This analysis was read by Dr. Gervis in the presence of Dr. Farr, who expressed himself as being gratified at the result of his suggestion and thanked the society for this valuable "contribution to the natural history of the British baby."

On July 18th of the following year (1870) Mr. Curgenven was commissioned to draw up a report on the changes in the law which appeared to be necessary in order to obtain greater security for infantile life, and on Nov. 7th the President (Dr. Graily Hewitt), Dr. Gervis, Dr. Braxton Hicks, Dr. Playfair, and Mr. Curgenven met and discussed Mr. Curgenven's suggestions, and, with some alterations, approved and adopted them. These recommendations ${ }^{6}$ were subsequently adopted by the council and it was resolved that they should be acted upon as the council might decide. Meantime another committee-consisting of Dr. Tyler Smith, Dr. Playfair, and Mr. Gaskoin-had been appointed on Oct. 19th (of the same year) to consider whether at the present time any steps should be taken for the promotion of obstetric education baving in view the interests of the public and of those interested in obstetric medicine. In the report of this committee, which was also adopted by the council, there occurs the following passage :-

The committee are also of opinion that there is at present an urgent need of some examination by which the knowledge of women practising as midwives should be tested, so that those patients who do not employ qualified practitioners should have some means of protecting who take upon themselves to practise midwifery. The committee who take upon themselves to practise midwifery. The committee therefore further recommend that a supplementary examining board should be formed for the voluntary examination of women preparing to practise as midwives, and for the granting of certificates of proficiency
to such as are found sufficiently qualified, and they believe it would be a noble object for the Obstetrical Society to endeavour to obtain eventually a legislative enactment preventing any woman from prac tising midwifery who has not submitted herself to some such examination.

With a view to giving practical effect to this suggestion a committee, consisting of Dr. Graily Hewitt (President), Dr. Barnes, Dr. Gervis, Dr. Hicks, Dr. Playfair, Dr. Tyler Smith, and Mr. Gaskoin, was appointed to submit a draft scheme. On Dec. 7th, 1870, the Infantile Mortality Committee (to which Dr. Meadows and Dr. Playfair had now been added) presented to the society its concluding report. This report had, like the previous one, been drawn up by Dr. Gervis. Before the report was read the President, Dr. Graily Hewitt, made a few introductory observations, in the course of which, after announcing that a series of "Rules for the General Management of Infants," drawn up by Dr. Playfair, had been approved by the council and printed for general circulation, he spoke of another and somewhat cognate subject that had " attracted the attention of the committee-viz., the desirability of urging on the legislature the necessity for various emendations in the laws relating to infanticide and the regulation and registration of the practice of midwives." $\mathrm{He}$ went on to say that $\mathrm{Mr}$. Curgenven, a member of the committee, had given special attention to this matter and would presently lay before the society the results

3 Transactions of the Obstetrical Society of London, vol. ix., for 1867, pp. $24,2 E$. 4 See Appendix I. (a)

5 Transactions of the Obstetrical Society of London, vol. xi. for 1869 , pp. 132-149.

6 See later. of the committee's deliberations upon it. It would.now rest with the society to move further in the matter and to press these subjects on the serious attention of the governing bodies of this country.

Accordingly, after the final report of the Infantile Mortality Committee had been read, the following "Suggestions for Legislative Enactments" were submitted to the meeting, the committee expressing itself as being "strongly impressed with the necessity of urging upon the Government some amendments to the existing laws and the enacting of other measures for the better protection of infant life." The "Suggestions "are arranged under several headings-as, e.g., (1) infanticide, punishment and evidence, amendments ; (2) registration of still-births; (3) education of midwives ; (4) boarding out of workhouse children ; and (5) registration of nurses (baby farmers). 'I he suggestions under No. 3 (education of midwives) were as follows :-

That no person should be allowed to perform the duties of a midwife or accoucheur unless he or she shall have received proper instruction and shall have given evidence before a competent examining board of possessing knowledge and experience adequate to attendance on cases possessing knowledge and experience adequate to attendance on cases the purpose of testing the knowledge of midwives and for the purpose the purpose of testing the knowledge
of issuing certificates of competency.?

At the annual meeting of the society, held on Jan. 3rd, 1872. with Dr. Braxton Hicks, the President, in the chair, the Council in a report to the society recommended a detailed scheme which had been prepared during the previous year by a special committee for carrying into effect the resolutions agreed to in December, 1870. The scheme was presented to the society in the form of new by-laws, ${ }^{8}$ which after some discussion were put to the meeting (at which there were present 60 Fellows, including the President) and passed unanimously. In moving the adoption of this addition to the by-laws $\mathrm{Dr}$. Graily Hewitt explained that the practical effect of the resolution would be to institute forthwith an examination for midwives. The plan submitted was the result of "continuous and matured consideration of the matter by the council." It involved the appointment of an examining board, composed of six Fellows of the society, "the examination to be held quarterly and to consist of a practical testing of the competency of the candidates to practise as midwives and of the possession on their parts of such an amount of knowledge as would enable them to recognise the presence of difficulties and the necessity for at once procuring competent professional aid for their patients. ..... That a formal guarantee of the efficiency of practising midwives was urgently required no one could doubt. This examination would supply that. It might be said possibly that the institution of such an examination was the duty of the Government or of the Royal College of Physicians or Surgeons, or the Society of Apothecaries. He was afraid that little was to be expected from Government action at present, though ultimately it might be hoped that this action of the society would result in legislation on the subject. Nor was it to be expected from the general governing medical bodies. In fact, what was everyone's business was the business of no one; and, under these circumstances, this society had stepped forward to initiate what was, he believed, universally admitted to be a laudable object, one indeed of pressing necessity."

The first examination under this scheme was held in 1872, the number of candidates, as will be seen from the table in Appendix $V$. at the end of this paper, being at first very small and showing no decided increase until after the first nine years. The first board for the examination of midwives consisted of Dr. J. Hall Davis (chairman), ${ }^{9}$ Dr. James $\mathbf{H}$. Aveling, Dr. Alfred Meadows, and Dr. Leonard William Sedgwick, with the two honorary secretaries (Dr. W. S. Playfair and Dr. John Jones Phillips) ex-officio.

On Nov. 21st, 1873, the President of the society, Dr. E. J. Tilt, the honorary secretaries (Dr. J. Jones Phillips and Dr. James H. Aveling), and several Fellows attended as a deputation to lay before the Right Hon. James Stansfeld, M.P., President of the Local Guvernment Board, their views with regard to the instruction and licensing, registration, and supervision of

7 Transactions of the Obstetrical Society of London, vol. xii. for 1870 , pp. 388 to 403

8 See Appendix II.

9 Subsequent chairmen were Dr. Alfred Meadows (1875-77), Dr. J. H. Aveling (1878-1883), Dr. (now Sir) John Williams (1884-86). Dr. J. Wat Black (1887-1890), Dr. F. H. Champneys (1891-94), Dr. C. J. Cullingworth
(1895-96). Dr. Percy Boulton (1897-1900), Dr. W. R. Dakin (1901-04), and Dr. John Phillips (1905). 
midwives. In explaining the object of the deputation Dr. Tilt said that he need not go into any lengthy statement as to the present condition of midwives in this country, as this had already been done by Mr. Ernest Hart, who recent]y attended with a deputation on the same subject and with similar objects from the Parliamentary Bills committee of the British Medical Association. He urged, however, that even from the point of view of national economy it would entail a smaller expense to the country to set the instruction and licensing of midwives on a reasonable footing than that which was being constantly incurred as a result of the large amount of preventable disease amongst parturient women of the labouring class caused by the incompetence of the women who habitually attend them. He informed Mr. Stansfeld that the Royal College of Surgeons of England, although recognising the importance of licensing midwives, and although permitted by its charter to undertake this duty if it chose, had recently determined, after careful consideration, to have nothing to do with it. He pointed out that the General Medical Council had, by a considerable majority, expressed its opinion that the midwives question demands serious investigation and had re-appointed a committee to report further upon the education, examination, and registration of midwives. In regard to the position of the Obstetrical Society in this matter, he described what had been done in the way of instituting quarterly examinations and gave a sketch of the circumstances which had led to this step being taken. "The candidates for our diploma," he said, "have not been numerous, but it is not difficult to understand why such is the case. It is clearly because our diploma has no legal value-no more value, indeed, than any certificate which any one of us may give in our individual capacity. I have told you what the society has done to remedy the evils it has discovered and 'suggestions' are now submitted to you which if carried out would, we believe, effect the object we desire. We do not think our soheme perfect. All that we want is to impress upon the Government that something should be done. We do not care whether we are made use of or not; we are ready to be made instrumental in effecting any good if any good can be done through us." On being reminded by Mr. Stansfeld that, departmentally, it rested not with the Local Government Board but with the Privy Council to deal with this subject, Dr. Tilt said that the deputation quite understood the position but had come to Mr. Stansfeld knowing the influence he could bring to bear upon the Privy Council. Dr. Aveling next addressed Mr. Stansfeld with reference to the "muggestions" of the Council of the Obstetrical Society, ${ }^{10}$ a copy of which had been forwarder to him a few days previously. An extremely interesting conversation in reference to these "suggestions" took place between Mr. Stansfeld and the members of the deputationwhich will be found reported verbatim in the Obstetrical Journal of Great Britain ans Ireland, Vol. I., 1873-74, pp 617 et seq. To this excellent report of the proceedings I am indebted for the preceding account and for the following brief references to some points that arose in the course of the discussion.

It has been stated, and repeated over and over again (by myself, I must confess, amongst others) that the estimate of 10,000 as being the approximate number of practising midwives in England and Wales, before the passing of the Midwives Act, was given on the authority of Mr. Stansfeld. It appears from the report of this interview that Dr. Aveling is responsible for these figures and not $M r$. Stansfeld. "I have calculated," said Dr. Aveling, "that the number (of midwives) required in England and Wales would be at least 10,000." With regard to registration, Dr. Aveling said it had been proposed that the General Medical Council might issue a sub-register in which the names of midwives might appear. The system of supervision suggested by the Council of the Obstetrical Society was certainly economical and he thought efficient. He quoted the example of Prussia, in which inspectors " are employed to go round and visit the midwives periodically. It is their duty to examine the diaries of the midwives and to abstract from them statistics which are of the greatest value. They investigate cases in which death has taken place during labour and hear any complaints which may be made." On Mr. Stansfeld inquiring whether he might take this as an indication of what the deputation would like to see adopted in this country, Dr. Tilt replied in effect "No," and added that they would rather advise " an

10 See Appendix III. approximation to the system adopted by the Government of France where the midwives are kept to certain strict regulations, such as that they should confine themselves to natural labours, and whenever the case requires it that they should call in a skilled obstetrician. Also that they should not use instruments, being liable to a fine of 100 francs for the first offence and double for the next."

Dr. Aveling had already asked Mr. Stansfeld to observe that the deputation looked upon the midwife "more as a midwifery nurse than as a medical woman," and Mr. Stansfeld now, after discussing what had been said as to the machinery to be employed in examining and licensing midwives, went on to deal with the training and instruction of women. "You desire," he said, "women to be midwifery nurses and not medical women. I do not see why you should confine the women to that position. ...... I do not see why you should place a restriction [upon a woman] if she has the. power of rising higher." This evidently alarmed some of the less advanced members of the deputation, for one of them here intervened to set Mr. Stansfeld right. "We think," he said, "that women should pass through a complete curriculum of medical education before they are allowed to treat diseases. We are quite willing that they should treat [patients] medically and use instruments if they have first. gone through a proper course of training such as is demanded of medical men." "But that question," replied $\mathrm{Mr}$. Stansfeld, "has not been raised; they do not use instruments, I do not see why it should be said that a woman should, unless she is to know the whole profession of medicine, know so much and no more. ...... I suppose in a great majority of cases nature will do its work, and if assistance is required which a woman cannot give it is even then a special kind of assistance, in that it is assisting a. natural action. I fail to see that it is impossible to accept the idea that a man or woman cannot become skilled in midwifery without having a complete medical knowledge. I do not say that midwives would be sufficient in all cases. I can quite. understand that there might be certain extremely dangerous cases in which it would be folly not to call in the best advice and skill but I do not see why you should say absolutely that a midwife unless she had received a medical education should be no more than a midwifery nurse. I should not be satisfied with any scheme that was not elastic and which did not give to women who had means and energy anà a desire to acquire higher knowledge and skill a position something above that of a mere mid wifery nurse." A member of the deputation here suggested that perhaps Dr. Aveling's phrase "midwifery nurse" had been unfortunate. "I do not say that," replied Mr. Stansfeld, "..... I desire to see: your rules elastic. I do not want to say to any woman, 'You shall be a midwifery nurse, but you shall not be permitted to learn more unless you pass through a whole medical curriculum.' ...... I always like to avoid unnecessarily restrictive rules. I like to trust to natural results." $\mathrm{Mr}$. Stansfeld concluded his remarks by promising to forward the views of the deputation to the Lord President of Council (Lord Aberdare) and to discuss them with him. "But do not consider me your spokesman," he added. "You should yourselves forward your suggestions to the Privy Council. I shall be able to say to Lord Aberdare that I take great interest in the matter and that I believe some scheme to be necessary." So ended an interview memorable in this - that the Minister not only understood and was interested in the subject but was so extremely sympathetic as to be prepared to go even greater lengths than the deputation itself in his efforts to give practical effect to the views they had come to place before him.

In discussing the midwives question on the occasion $I$ have just been describing Mr. Stansfeld suggested that. besides the midwives wanted by the labouring classes there should be another class, better instructed, who should be allowed to attend to unnatural labours without having received a complete medical education. Dr. Tilt referred to this proposal when he spoke in his next annual address of the deputation to Mr. Stansfeld and said that in his opinion the State would be going beyond its duty if it did more than provide for the poor midwives qualified to attend natural labour. "It will not be so very easy," he continued, "to find funds for the maintenance and the tuition of midwife pupils for a year so that the poor may have midiwives not too proud to live in villages and in back slums nor beneath taking $5 s$. as a usual fee for a midwifery case, but to ask Government to provide for the board and tuition of women for three or four years, so as to manufacture 
a superior kind of midwife, would be asking Parliament to found a medical college for women, which it would never do." In the same address of Dr. Tilt there occurs the following passage, which although written in 1874, is not without interest in the year 1907: "During the last few years a very small group of noisy women have been declaiming and writing about the rights of women. It will neither be for the good of society nor for the happiness of women that they should assume our habits, occupations and anxieties, in addition to their own which they cannot possibly throw off; but at all events one would have thought that the first use these energetic women would have made of their newly acquired eloquence would have been to claim for thousands of English women of the speechless poorer classes the first right of woman in all civilised countries, the right of being safely delivered of their children. Here was indeed a woman's question, a theme suggestive of eloquence, pregnant with pathos; but no, they leave it to us to plead for their sisters, and spend their time in clamouring for the right of voting

remained true to the end that those women who were the most strenuous advocates of women's rights were singularly apathetic in regard to legislation for midwives. With one or two exceptions the medical women also held aloof in a very remarkable manner, the women who really took an interest in the subject and worked at it for years with an amazing perseverance being a group, not of medical women, but of educated midwives.

Although not strictly within the scope of this paper, I cannot resist the temptation to allude to another deputation that waited upon Mr. Stansfeld very shortly after the one of which I have been speaking. On Dec. 8th, 1873, a small body of women (amongst whom were Miss Firth, who introduced the deputation, Miss Fenwick Millar, and Mrs. Noel Thatcher) attended at Gwydyr House to lay before $\mathrm{Mr}$. Stansfeld a memorial from the Obstetrical Association of Accouchers (sic) and the midwives of London who were not members of that association. This memorial stated, inter alia, that the council of the Obstetrical Association of Midwives (sio), feeling that a legal status for midwives was desirable and requisite, had, on Dec. 20th, 1872, addressed a letter to the Royal College of Surgeons of England asking it to grant an examination in midwifery and licence or certificate to midwiwes, and that the Council of the Royal College of Surgeons had refused to do this, stating that it had no intention of altering its present regulations. But the principal object of the memorialists obviously was to call attention to what they considered objectionable features in the suggestions laid down by the recent deputation from the council of the Obstetrical Society of London. These were: first, that the attendance of a midwife should be limited to natural labour; secondly, that midwives are not to treat obstetric emergencies; thirdly, that the present corporate bodies are not to be expected to undertake the examination of midwives fourthly, that the Obstetrical Society of London has instituted an examining board for midwives and is willing to undertake their examination, licensing, and registration and fifthly, that the midwives require supervision lest they should neglect or exceed their duty.

The otjections to these proposals were set forth at some length. The memorialists considered the limiting of a midwife's practice to natural labour an evil, "inasmuch as the obligatory sending for a medical man lessens her sense of responsibility, while it offends her and lowers her status in the eyes of her patients." A properly trained midwife would be competent to undertake the management of obstetric emergencies and would be "capable of recognising any condition requiring medical aid." They did not think that men had " any right to say to a woman able and willing to assist $h \in \mathrm{r}$ sex to the utmost, "thus far shall you go but no further.' If a patient preferred a midwife to attend her, that patient had a right to expect her attendant to be competent to deal with any obstetric emergency that might arise." They considered that the Obstetrical Suciety of London, being a private and not a corporate body, had no legal right to institute an examining bourd, and that inasmuch as the founder of the societiy had definitely expressed the opinion that "it should be the steady aim of every one in obstetric practice to discourage-the time perhaps having scarcely arrived when they could abolish-midwife practice," and as the Obstetrical Society's policy had been and was founded on that advice, it would be impossible to devise a more unfair board-"a body," they exclaim, "of avowed enemies sworn to our destruction, pretending to cherish and foster us." As to the necessity for supervision, midwives as a class were not in the habit of either neglecting or exceeding their duty. Supervision was no more needed by them than by medical men. Regulations embodying the idea that men and women must be dealt with under different codes of moral law were false and ought not to be encouraged or permitted.

Mr. Stansfeld said that he had not observed in the speeches made to him by the deputation from the Obstetrical Society any trace of antagonism to the position the women desired to take, however much their detailed rules might seem to support such a charge. He understood the present deputation to want facilities to be afforded for the education, training, certification, and registration of women ready to perform all the functions of midwifery, and he did not see why they should be refused these facilities by the legislature. With regard to the Obstetrical Society's undertaking the duties of examining and certifying midwives, although it was willing to do it, it was equally willing that the work should be undertaken by the Royal College of Surgeons or any other body, and he for his part thought it would be preferable for one of the licensing or degree-giving bodies to undertake these duties. He had not yet satisfied his own mind as to what would be the best scheme, but he thought there should be elasticity in any scheme adopted so as to admit the practice of women who were ready to fulfil all the functions of midwifery. ${ }^{11}$

I have related this episode at perhaps disproportionate length because it is not of ten that such definite expression is given to the views set forth by these memorialists. It has been too often forgotten in the conrse of the many bitter controversies which the midwives question has provoked during recent years that there is a midwives' point of view as well as a doctor's, and that although the primary object of midwives legislation is to benefit the labouring classes no legislation can be satisfactory or successful which is unfair either to the medical profession or to the midwives. The medical profession has been heard on the subject-shall I say ?-ad nauseam; the midwives are heard but seldom. When they do speak they should have a patient hearing.

In his annual address at the Obstetrical Society of London, delivered on Jan. 6th, 1875, Dr. Tilt, the retiring president, after reminding bis hearers "that the lower classes of society were at the mercy of nneducated midwives," wholly "un. controlled," except by "the fear of a coroner's inquest," went on to allude to the prospects of legislation. "Last year," he says, "Lord Aberdare and Mr. Stansfeld were in office; they favourably entertained the views repeatedly brought forward by the society and they were prepared to bring in a Bill for the better education ard registration of midwives when a change of Ministry convinced your council that the question must be left in abeyance. ...... It will be for the new council to decide whether it is not time to reocen the question with the present Ministers." 12 It appears that the new council did consider this matter and that it decided to take action, for on March $9 \mathrm{th}, 1876$, a deputation on the training of midwives, comprising representatives of the Obstetrical Society of London, of the Social Science Association, of the Infant Life Protection Society, and of the Pariamentary Bills Committee of the British Medical Association, was received by the Duke of Richmond, Lord President of the Privy Council, and Mr. Sclater Booth, President of the Local Government Board. The deputation included Dr. Arthur Farre, Dr. (afterwards Sir) William Priestley, Dr. Aveling, Mr. Ernest Hart, Dr. Graily Hewitt, Dr. Tilt, Dr. Braxton Hicks, Dr. (now Sir) Constantine Holman, Mr. Heckstall Smith (St. Mary Cray), Dr. Grigg, Dr. Wiltshire, Dr. Edis, Dr. (now Sir) John Williams, Mr. Francis Fowke, Mr. Curgenven, the Rev. Oscar Thorpe, Dr. J. B. Potter, and many others. With the Lord President were Lord Sandon (afterwards the Earl of Harrowby), vice-president of, and Mr. (afterwards Sir) John Simon, medical officer to, the Privy Council. The deputa. tion was introduced by the Right Hon. Lyon Playfair, M.P. (afterwards Lord Playfair), Sir Trevor Lawrence, Bart. M.P., and Mr. James Lewis, M.P. The President of the Obstetrical Society of London (Dr. Priestley) explained the object of the deputation-viz., to obtain skilled attendance for the poor during their confinements, and concluded by

11 See Obstetrical Journal of Great Britain and Ireland, vol. i. 1873-74, pp. 689-E96.

12 Transactions of the Obstetrioal Society of London, rol. xvii., for 1875, p. 33 . 
directing the attention of the Lord President to some suggestions which had been drawn up by the council of the society. ${ }^{13}$ Mr. Ernest Hart and Mr. Curgenven supported the objects of the deputation. The Duke of Richmond spoke of the influential character of the deputation and said that he fully recognised the unselfish objects of the Obstetrical Society of London and of the other bodies represented. He was disposed to regard the matter as of great importance and the proposed methods he considered reasonable. The subject, however, was a difficult one and he could only promise to do his best to treat it satisfactorily. ${ }^{14}$

In February, 1877, Dr. Charles West, in his inaugural address as the new President of the Obstetrical Society of London, lamented the small number of candidates presenting themselves for the society's examination (only some five or six annually), and advised the society "either to renounce a futile endeavour or else to take steps to bring that endeavour to a real fulfilment," by preparing and submitting to the authorities a "carefully digested plan," as the society neither conld " nor ought to expect to gain anything by asking them to do a something without knowing rightly what."

In May, 1877, a deputation from the council of the society again waited upon the Lord President of the Council who expressed himself as favourable to the principles embodied in the amended scheme submitted to him. This scheme was afterwards laid before the General Medical Council, which also approved of its object. In alluding in his presidential address to what had been done during the year 1877 in the direction of urging upon the Government the necessity for legislation Dr. West made graceful reference to the unwearied zeal of Dr. Aveling, "without which our progress towards this most desirable end would have been very small." The President went on to express a conviction that has not by any means lost its practical interest and significance--viz., that it would not be "desirable to substitute for the proposed plan of various examining boards and various registration districts throughout the country any scheme which would imply the formation of one central board for examination and registration under the control of the Local Government Board." He concluded his remarks on the midwives question on that occasion by expressing the hope "that all the Fellows of the society" would " persevere in the endeavour-which concerns us, not as doctors, but simply as citizens striving to supply a great social want-to secure some guarantee that the poor shall not continue to be exposed to an ignorance and unskilfulness against which the Government of every other civilised country has protected them."

In the year 1878 the Duke of Richmond embodied (in a permissive form) the principles of the scheme, submitted to him by the council of this society, in the Medical Acts Amendment Bill. The portion, however, relating to midwives was subsequently dropped out of the Bill, and the Bill itself, owing to the troubles arising out of the Russo-Turkish war, had eventually to be abandoned.

"Medical legislation," said Dr. West in 1879, "is at the best beset by so many difficulties, requires the conciliation of so many conflicting interests, and, unfortunately, gives an opportunity for people to indulge so many crotchets, that it has seemed to some of us it might be desirable to detach this simple practical matter from the wider question and to endeavour to get a Midwives Bill introduced separately into one or other of the Houses of Parliament." As a matter of fact, the separation of the one question from the other had not the result Dr. West seems to have anticipated, for more than 20 years elapsed before any Midwives Bill became law, the event proving that the difficulties to which Dr. West alluded as besetting medical legislation beset midwives' legislation in at least an equal degree.

At the annual meeting of the society held on Feb. 4th, 1880, the Board for the Examination of Midwives, for the first time since its formation in 1872 , presented a report. This report, which was signed by the chairman (Dr. Aveling), stated that in the eight years during which the board had been in existence 54 candidates had presented themselves for examination. Of this number 47 had satisfied the examiners and seven had been rejected. During 187913 candidates had come up for examination, a number much above the average. The candidates had for the most part been well-educated women. It had been exceptional

14 Obstetrical Journal 13 See Appendix IV.

$1876-77$, p. 60 to meet with one from the working classes, which the board considered unfortunate, as that was the class of woman which it was most necessary to reach. The board concluded its report by expressing its opinion " that the tentative action of the society, in providing a public test for skilled midwives" had "been useful only to a very limited extent; and that nothing short of legislative measures can insure the instruction of the hundreds of women who practise midwifery in this country." The board considered it "most desirable that the council should not relax in the landable exertions which it has during the last few years been making to induce the Government to recognise the importance of ameliorating the present condition of midwives and providing for the safety of poor women in childbirth." A Bill devoted entirely to this subject and not connected with any scheme for medical reform would, "in the opinion of the board," have the best chance of being dealt with by Parliament. In commenting upon this report the President, Dr. W. S. Playfair, in his address delivered on the same occasion said that "in founding an examination the society had no intention of assuming to itself legislative functions, but it hoped that its action might direct public attention to this question and that the legislature might eventually take the matter in hand. "There is good ground for believing," he continued, "that a Bill on this subject will ere long be submitted to Parliament, and in that case our scheme of examination will be useful in indicating the lines on which such a measure should be based. Early in the year," he said, "I had the honour of heading a deputation to the Lord President of the Council ${ }^{15}$ urging the necessity of this on the Government, which was courteously and favourably received. The Government had already taken this matter into consideration in their Medical Bill, in which there was provision for the formation of a register of midwives." This provision "was, however, simply permissive and would," the President thought, "have been practically useless." "When," said he, "the question is settled our Board of Examiners will, I am sure, gladly perform the operation of the 'happy despatch' and cease their functions."

So far as I have been able to find out, the occasion mentioned by Dr. Playfair was the last on which a deputa. tion to Government ${ }^{16}$ went up from the Obstetrical Society of London. Other deputations on the subject continued to be received from time to time by the Lord President of the Council and other members of the Government for the time being, but any Fellows of the Obstetrical Society of London who formed part of these deputations attended in their individual capacity and not as representing the society. I have no reason for supposing that this arose from any change of opinion on the part of the society or of its council. It was probably due to a feeling which found forcible expression in the inaugural address of Dr. Playfair's successor in the presidential chair, Dr. Matthews Duncan. "The society knows well," he said, "that political interference is a mere accident of public utility arising from the position it has otherwise attained. The great work of this society is not political. ...... The wisest judges of our society will pay but scant attention to our political proceedings, and so also will our best members. ..... This society will pay due attention to its political work as it arises, but it must devote its best energies to its scientific work." I7 With these words from the lips of perhaps the strongest and most influential president the society had ever had ringing in its ears and commending themselves to its deliberate judgment, the council could scarcely be expected, for some time to come at least, to take any very active part in the politics of the midwives question. It was accordingly content to go on quietly conducting its examinations, leaving to others the duty of promoting legislation. Of the examinations instituted by the society Dr. Matthews Duncan cordially approved. "This good scheme," he said, "has had an encouraging amount of success....... But this does

15 This interview took place on March 14th, 1879. A report of the proceedings was published in the British Medical Journal, vol. i., 1879, p. 449.

16 A deputation from the Council did, however, in 1885 wait upon Sir John Lubbock (afterwards Lord Avebury), at that time Member of Parliament for the University of London and Treasurer of the Roya Maternity Charity, to endeavour to induce him to take up the question of the examination and registration of midwives and to introduce Bill. But with a dissolution and general election impending the moment was not considered propitious and it was thought prudent to abstain from further action for the present.

17 Transactions of the Obstetrical Society of London, vol. xxiii. (for 1881), London, 1882 , pp. 66 and 67. 
not satisfy us. We want a recognised legal position, chiefly registration, for graduates and we desire a great increase of the numbers tanght and seeking our diploma. ...... Indeed, the improvement and extension of the practice of ordinary midwifery by women is a most desirable object. Many people," he said, "still living remember the time when the whole of this practice was in female hands. It was taken from them by the other sex, not because they were male but in consequence of their superior education and scientific attainments. ..... If women are to be re-instated in the practice of midwifery, whether in unnatural or in natural labour, it is education and science alone that can do it, and women may be sure that these are irresistible. Meantime we are interested only in the extension of women's usefulness in ordinary cases, natural or nearly natural ; and our object is to secure for the public a class of such women, reliable, because duly qualified." From which remarks it seems bighly probable that Dr. Matthews Duncan would have sympathised with the views expressed some years previously by Mr. Stansfeld at the interview already described.

From 1880 onwards the chairman of the board of examiners presented a report annually. After having been a member of the board of examiners for 12 years and its chairman for six years Dr. Aveling, at the end of 1883, retired from the board. In his farewell report he suggested that in future the examiners, who had hitherto given their services gratuitously, should receive some sort of honorarium. The suggestion does not appear to have been acted upon immediately, but a few years later, the number of candidates having by that time considerably increased, it was decided that the examiners should be remunerated and, accordingly, in 1888, "fees to examiners" occurs for the first time as an item in the treasurer's accounts. For the first 16 years, therefore, or nearly one-half of the entire period during which the society continued to hold its examinations, the examiners received no remuneration at all. After that they received a proportion of the candidates' fees.

Hitherto the action of the council in carrying on a system of voluntary examinations for midwives and in supporting the efforts of those who were anxious to secure legislation on the midwives question had never been challenged by the general body of Fellows, but at the annual meeting held on Feb. 4th, 1891, the whole matter was brought up for discussion. An agitation had arisen amongst the medical practitioners of the country in opposition, nominally to a Midwives Bill introduced into Parliament by Mr. Pease, but really directed against any recognition of midwives either by Parliament or by any voluntary examining body. It is not within the scope of this article to enter into matters of controversy, but in order to explain the attitude of the council of the society from this time forward it is necessary to mention that a certain number of the Fellows of the society sympathised with the agitation and endeavoured not only to prevent the society from supporting the proposed legislation but also from continuing its own voluntary examinations. In regard to the former it succeeded partially; in regard to the latter not at all.

The council never again adopted a scheme of legislation or prepared a Bill. The utmost it ever did in that direction was (at the request of the promoters) to consider the Midwives Bill of 1890 in detail and to suggest certain alterations, most of which were adopted by the committee in charge of the Bill but were swept away again when the Bill was taken up, as it was for a while, by the Government. Ultimately the council expressed itself as "in no way responsible for the present Bill, ${ }^{18}$ though it emphatically approved of the principle of examination and registration of midwives, and saw no reason to depart from the view continuously held by all previous councils of the society." This attitude of the council was supported by the general body of Fellows assembled at the annual meeting in 1891, when the following

18 This Bill was eventually talked out by $\mathrm{Mr}$. Bradlaugh, as a protest against a certificate of moral character being required before registra tion in the case of midwives when no such certificate was required in the case of medical practitioners. Other Bills were introduced in 1895 1896, 1897, and 1898, by Lord Balfour of Burleigh, Mr. Cosmo Bonsor, Mr. Tatton Egerton. and Mr. J. B. Balfour respectively, but owing in the case of the 1895 Bill to a change of Government, and in the case of the other Bills to the Government requiring the day fixed for the second reading for its own business, none of them came to a vote. The secon reading of the 1900 Bill. introduced by $\mathrm{Mr}$. Tatton Egerton, was move by Mr. Heywood Johnstone. It got as far as the report stage, when Mr. Heywood Johnstone deemed it prudent to talk it out. The (1902) Mr. Heywood Johnstone taking charge of it in its subsequent stages. motion was moved by Dr. Aveling, seconded by Dr. W. S A. Griffith, and carried with but two dissentients: "That the Fellows approve the policy pursued by this society for the last 20 years relating to midwives, and respectfully request the council to continue their efforts to obtain for these women suitable education and legal registration."

Meantime the agitation in the country assumed larger proportions. A large number of medical practitioners, being assured that their interests would be imperilled if midwives received any kind of State recognition, took alarm and ranged themselves on the side of the opponents of legislation. Resolutions deprecating legislation were sent to the Genera Medical Council and letters were written to it calling attention to the certificates and diplomas granted by the Obstetrical Society of London and other institutions and persons to midwives who had successfully passed an examination. The General Medical Council had, in 1889, passed a resolution strongly urging the need for legislation on the subject, but in consequence of the representations now made to it it henceforth adopted a new policy. From December, 1892, up to March, 1895, a correspondence went on between the General Medical Council and the Council of the Obstetrical Society of London regarding the form and wording of the diploma or certificate issued by the society to those midwives who successfully passed the society's examination. The General Medical Council took exception to the society's diploma as being a colourable imitation of a diploma conferring a legal right and admission to the Medical Register, and intimated that if the society continued to iss ue this diploma such conduct would be regarded by the General Medical Council as being "infamous in a professional respect." The upshot of the whole matter was that the word "certificate" was substituted for the word "diploma," that the size of the document was rednced, that the figure of Lucina and the seal of the society were banished from it, and that the words "skilled midwife" were no longer employed. The new certificate differed from the old as tweedledum differs from tweedledee, and so the episode ended, the result being a net gain to the society in that its examination and certificate had now received an official recognition which they had not previously possessed

The work of the society suffered no further interruption. ${ }^{19}$ Being thus finally relieved from the necessity of detending itself against attack, the council was able to give its attention to certain much-needed improvements in what may be called its domestic policy. For example, up to the year 1898 midwives holding the society's certificates had had no rules for their guidance, printed or otherwise. This was felt to be an anomaly, especially as, since 1889 , every candidate on receiving her certificate had been required to sign a declaration that she would faithfully obey the rules. Accordingly, the council and the board for the examination of midwives were formed into a joint committee to prepare a code of rules and regulations, and in July of the year just mentioned these rules were printed and published by the council, a copy being posted to every midwife whose name was on the society's roll, with an intimation that henceforward she would be required to conform to them. A copy was also from this time onward presented to each successtul candidate along with her certificate. For the information of the Fellows and for purposes of reference the rules were printed in the Society's Transactions for 1899. Considering that it was impossible for a voluntary association like the Obstetrical Society of London to organise anything like an adequate system of supervision over those who had received its certificates, or in cases of misconduct, to impose penalties other than the extreme penalty of confiscating the certificate, the disciplinary

19 A further attempt was, however, made in November, 1899, to put a stop to the society's examinations. At a meeting of the General “(1) That passed on May 27th, 1895. the Registrar be instructed that the Council can no longer assent to the holding of examinations in midwifery or to can no longer assent to the holding of examinations in midwifery, or to any body of persons, unless invested with practice of that art. by examinations and grant certificates in this branch of medicine examinations and grant certificates in this branch of medicine. (2) That the Registrar be instructed to insert notices in the leading medical journals to the effect that on and after the 15th day of January next any registered practitioner who takes part in any examination in the art and practice of midwifery, or any other branch of medicine or surgery held by, or on behalf of, any society or person, or body of persons unless legally authorised to hold such examinations and grant certificates of proficiency to successful candidates will be liable to be adjudged guilty of infamous conduct in a professional respect and to have his or her name removed trom the Medical Register. Something moving of the "previous question." 
difficulties that arose in connexion with this branch of the society's work were singularly few. Inquiries were occasionally called for into cases of alleged misconduct and in a few instances, so few as to be capable of being counted on the fingers of one hand, the charges were substantiated and the certificates of the accused were cancelled.

Meanwhile, the society's certificate became recognised throughout the Empire as evidence of its holder's competency to attend ordinary cases of labour. It was " accepted as such by the Army Medical Department, by a large number of boards of guardians, nursing associations, and maternity societies." Being entirely independent of the training institutions, it acquired from that circumstance alone a unique value. The examiners who conducted the examination were in many instances the same who examined the candidates for medical degrees at the universities and for the qualifying diplomas of the Royal Colleges of Physicians of London and Surgeons of Eng and and the Society of Apothecaries. The Queen Victoria Jubilee Institute of Nurses expected those of its nurses who took up midwifery to qualify themselves by undergoing the training enjoined by this society and passing its examinations, whilst the Midwives Institute made it a condition of membership that the applicant had obtained the society's certificate. It is no wonder, therefore, that the number of candidates increased to such an extent that extra examiners were required from time to time and that the premises in Hanover-square, extensive as they are, became too small for the purpose. No doubt the final rush was in some measure due to the impending establishment of a State examination. Candidates, not knowing what the nature and scope of the new examination were likely to be, hastened to avail themselves of an examination that they knew something about, but apart from that, as the appended table shows, the rate of increase had been very considerable even before the Midwives Act of 1902 had been passed. When, therefore, at the beginning of 1905 the society's examinations were superseded by the State examinations of the Central Midwives Board, as it had all along been the desire of the society that they should be, the society could look back upon this branch of its work with the gratifying consciousness that it had, in the words of $\mathrm{Dr}$. W. R. Dakin, "succeeded in raising the standard of education of the midwives of this country and in helping to safeouard its mothers and new-born children." "If," continues Dr. Dakin, "the scciety had never done more than this, it would assuredly not have lived in vain." 20 "It is not too much to say," say s the same writer in addressing the Fellows of the society ${ }^{21}$ on another occasion, "that regarding it from a national point of view, the work that this society has done is a more useful one than has ever before been accomplished by any medical scientific society. ...... You have educated more than your midwives. ..... For unless you had shown, in the persons of those women who were considered worthy to receive your certificate, what a midwife might be made, the public could not have been stirred to the pitch of discontent with the old type " that ultimately rendered legislation inevitable and was certainly the immediate cause of the passing of the Midwives Act.

\section{APPENDIX I. (a)}

The following is an extract from that part of the first report of the Infant Mortality Committee (presented June 2nd, 1869) which has reference to midwives : -

"The first question asked related to the proportion of births attended by medical men and by women respeclively, to the amount of instruetion possessed by the women, and to the mode of procedure adop' ed with the infant immediately after its birth. From the replies given the following general statements are deduced, - that among the poor population of villages a large proportion, varying from 30 to 90 per cent., are attended by midwives. Thus in Fleggburgh in Norfolk, with midwives. In Gringley, near Bawtry, Notts, with a population of 874 , Mr. Raynes reports the number as 46 per cent., and at Bromyard, in Mr. Raynes reports the number as 46 per cent., and at Bromyard, in as 90 per cent. are attended by midwives. In the small nonmanufacturing provincial towns, on the other hand, attendance
by midwives prevails to a much less extent, with a few exceptions. by midwives prevails to a much less extent, with a few exceptions. The large majority of the returns puts attendance by midwives in
towns of a population of from 6000 to 10,000 , as varying from 5 to 10 per towns of a posulation of from 6000 to 10,000 , as varying from 5 to 10 per cent., and in some few as not occurring at all-e.g. in Lewes, with a
population of 3716 , there is stated to be none. In Long Sutton, howpopulation of 3716 , there is stated to be none. In Long Sutton, how-
ever, with a population of 6124 , Mr. Ewen rer orts that attendance by ever, with a population of 6124, Mr. Ewen ref orts that attendance by
midwives oceurs to the extent of 26 per cent, ; in Altrincham ia midwives occurs to the extent of 26 per cent.; in Altrineham in Cheshire, with a population of 6628, Mr. Blease reports that attendance
by midwives reaches as high a figure as 53 per cent. In the large

20 Report of the chairman of the Board of Midwives, December, 1904, Transactions of the Obstetrical Society of London, vol. xlvii. (for 1905), 979

21 Inaugural address, Transaction
London, vol. xlvii. (for 1905), p. 124. provincial towns, and especially in the large manufacturing towns, attendance by midwives among the labouring population occurs in almost as large a proportion as in the agricultural villages. Thus, in Shetfield, Birmingham, and Bury the proportion is not stated in figures but stated either to be large or the larger, in comparison, $i$ e., with attendance by qualified practitioners. In Wakefield, however, with a population of $23.000, \mathbf{M r}$. Fowler reports that while among the Irish attendance by women prevails to a very large extent, among the English nearly every case is attended by a medical man. In kdinburgh, as reported by Dr. Matthews Dunean, attendanee by midwives would appear to occur to but a trifling extent. Lastly, from London the reports vary accordingly as they came from the East or West, or from Stratford, it would appear that from 30 to 50 per cent. of the poor are attended by miduives. In the West Wnd, on the otber hand, the proportion is very slight; thus Mr. Curgenven, Dr. Bloxam, and Mr. such as Wimbledon Dr. Payne states the proportion of midwifery attendance by women to average about 5 per cent.

"To the question, 'Are the women instructed?' answers in the negative have been received from all parts of the country, with the negative have been received from all parts of the country, with the
exception of Glasgow and Sheffield, where Dr. Yeaman and Mr. IIime exception of Glasgow and Sheffield, where Dr. Yeaman and Mr. Hime
respectively report a certain amount of education to exist among the respectively report a certain amount of education to exist among the
better class of midwives. From several districts the replies indicate better class of midwives. From several districts the replies indicate not merely a want of any special education but gross ignorance and incompetence, and a comp'ete inability to contend with any difficulty
that may occur. In London, on the other hand, it would appear that may occur. In London, on the other hand, it would appear
there are many women practising mid wifery who have received a certain amount of instruction at various institutions, but these although fairly competent in ordinary cases, are also quite unequal to any of the emergencies of obstetrics." 29

Appendix I. (b).

Extract from the Final Report of the Infantile Nortality Committee,

presented to the Obstetrical Society of London on Dec. 7 th, 1870 .

"In the first report there was no reply from Wales; to the seeond circular five l'ellows have responded. With respec; to the proportion of births attended by medical men and midwives respectivel. $\mathrm{y}, \mathrm{Mr}$. Evan Jones of Aberdare states that all the lower classes are attended by women, medical men being only called in in emergencies; Mr. Roberts of Rhyl puts the number at about one-half; Mr. Morgan of Llanelly, 80 per cent. by women; Dr. Jones of Ruabon, 90 per cent. by women;
and Dr. Gwyne Harries of Pembroke Dock, more than a half by and Dr. Gwynne Harries of Pembroke Dock, more than a half by
women. It may be concluded, therefore, that throughout the Princiwomen. It may be concluded, therefore, that throughout the Principality, and more especially in the mining districts, the attendance of the lower classes is mainly in the hands of midwives, and of these would $b \rightarrow$ very desirable (writes Mr. Evan Jones) if something could be done to prevent midwives acting as nurses in fevers and other contagious diseases and to prevent them from laying out dead bodies. In nearly every case of puerperal fever that has come under my notice no medical man attended the confinements."

"Passing now to the replies from our English Fellows. To the first question 70 fresh intormation from villages has been received, but the statements of the first report as to the other classes of towns. have been confirmed. Thus in Alnwick, Reigate, and Gravesend, towns
containing populations of $8000,10,000$, and 18,000 , the returns are containing populations of $8000,10,000$, and 18,000 , the returns are
respectively 30 per cent. by women, very few by women, and less than 5 per cent. by women. In two ot her towns, however. nearly as largeviz.. Bideford, with a population of 57,0 , and Dorchester, with a population of 6800 - the attendance by midwives is higher; in the first it is put at $7 j$ per cent. and in the second at 65 . But both of these towris partake of much of a strictly rural character. The return from expressed on the other hand, entirely corrobsrates the opinion being attended by women. Lsstly, Dr. Brunton, writing from the 30 per cent. All unite in stating that the midwives are uninstructed except in the case of a tew practising in London."

\section{APPENDIX II.}

The New By laws respecting Examinations for Midwives, adopted or Jan. 3ra, 187

"By-laws, Chap. XVI.-I. That an Examining Board be formed, consisting of six members-viz., a chairman, three ordinary members, and the honorary secretaries ex-officio (the two non-official members of the
Board longest in office to retire annually). - I . That examinations be Board longest in office to retire annually). - II. That examinations be
held at the Society's librarv on the second Wednesday of the months of January, April, Julv, and Octoher at eight o'clock P.M. or at such times as the Board of Gxaminers may from time to time determine.III. That candidates for admission to the examination be required to submit to the honorary secretaries of the Society certificates of the following qualifications at least 14 days before the date of the examination: (a) a certiticate of moral character; $(b)$ a certificate showing that the canclidate is not under 21 years of age and not over 30 years of age, but that up to the year 1877 candiclates above 30 years of age be admitted to examination under special circumstances satisfactory to the Board of Examiners ; (c) proof of baving attended the practice of a lying-in hospital or charity for a period of not less than six months, or of having personally attended not less than 25 labours under supervision satis factory to the Board of Examiners; $(d)$ proof of having attended a course of theoretical teaching by lectures or tutorial instruction, the details of which must be submitted to, ard receive the approval of, the Board of Examiners. - IV. That the candidates be required to pass (1) a following subjects: $(a)$ the elementary anatomy of the female pelvis and generative organs; (b) the symptoms, mechanism, course, and management of natural labour; (c) the indications of abnormal labour and the emergencies which may occur in practice; $(d)$ a general knowledge of the puerperal state; $(e)$ the management of new-born children and infants; $(f)$ the conditions as air, food, cleanliness, \&c, necessary with regard to the seeking of medical advice.-V. That, on satisfying 
the Board of Examiners as to her qualifications, the midwife should receive a diploma certifying that she is a skilled midwite, competent to attend natural labour.-VI. That the fee for this diploma be one guinea and that unsuccessful candidates be rerquired to pay a fee of five shillings."

\section{APPENDIX III.}

"Suggestions for the Instruction, Earmination, Licensing, Registration and supervision of Midwives submitted by the Council of the Obstetrical Society of Londion in an interview with the Right ITon. James Stansfeld, M.P., on the $\approx 1$ st of November, $18 \% 3$.

"Definition of a midwife.-A healthy, sensible, respectable woman able to read, write, and calculate, understanding the management of natural labour and the ordinary care of the mother and child after labour, and capable of recognising any conditions requiring medical aid during the parturient and puerperal states.

"Instruction of millwives - This might be done by utilising the present lying-in charities and unions. Theoretical instruction might also be given by qualified medical men, and practical instruction at the bedside given by qualifien medical men, and practical instruction at the bed side it is neither necessary nor desirable to congregate a large number of it is neither necessary nor desirable

"Examination and licensing of midwives-As no one can treat obstetric emergencies and diseases successfully until he or she has first fulfilled a complete medical curriculum such as qualined medical men are compelled to undergo, and as it is not proposed that such knowledge should be required of midwives, it can scarcely be expected that the universities, colleges, and corporations that license medical men would undertake the examination of midwives. The Obstetrical Society of London, having had repeatedly and urgently brought before its notice the sacrifice of human life and health occasioned by the practice of ignorant midwives, has already instituted an Examining Board for testing the knowledge of women desiring to follow the calling of a midwife, and has granted certiticates to those who have satisfied its examiners. The Society is therefore able and is willing to undertake the examination, licensing, and registration of midwives if the Privy Council think it desirable. It would be necessary for the Society to have the power of instituting branch examining boards in the provirices. A similar method of examination and licensing might be carried out by examining

"Registration of midwives. - It is believed that nothing short of compuisory registration of midwives will afford safe attendance during labour to those who are unable to distinguish between a good and a bad minwife. In future every woman undertaking the duties of a midwife in England and Wales should be required to pass the society's examination prior to registration, and no public appointment should hereafter be given to any midwife who is not registered. It is also thought desirable that all midwives at present in practice shonld, on the production of satisfactory evidence of fitness for the calling, be eligible to be placed on the register.

"Supervision of midwives.-Seeing that great injury might accrue to the public from the midwives thus registered neglecting or exceeding their duties, the Council deem it highly desirable that some mode of supervision should be adopted. This would perhaps be most easily effected by the renewal of annual licenses upon the production of a certificate of good character signed by a minister of religion, a magistrate, or a qualitied medical man. It is also considered necessary that power should be given to the Examining Board after due investigation to erase from the register the name of any midwife who has grossly misconducted herseli."

\section{APPENDIX IV.}

"Suggestions drawn up by the Council of the Obstetrical Society of London and laid bejore the Lord President of the Privy Council (the Duke of Richmond) and the President of the Local Government Board on the 9 th of March. $18 \% 6$, by a deputation from the Obstetrical Society and other public bodies.2.

"Definition of a midwife.-A respectable woman, able to read, write, and calculate, understanding the management of natural labour and the ordinary care of the mother and child after labour, and capable of recognising any conditions requiring the aid of a medical practitioner during the parturient and puerperal states.

"Instruction of midwives.-This might be done by utilising the present lying-in charities and unions. Theoretical and practical instruction might be given by authorised medical practitioners and practical instruction might also be given by registered midwives.

"Examination and licensing of midrvives. - This would be best accomplished by a board of examiners especially formed for the purpose.

"Registration of miduives.-It is believed that nothing short of compulsory registration of midwices will afford safe attendance during labour to those who are unable to distinguish between qualified and unqualified midwives. In future every woman determining to be registered as a midwife in fingland and Wales should be required to pass the recognised examination prior to registration; and no public appointment should hereafter be given to any midwife who is not so registered. It is also thought desirable that all midwives at present in practice should, on the production of satisfactory evidence of fitn

for the calling, be eligible to be plared on the register of midwives.

injury might accrue to the public from registered midwives neglecting or exceeding their duties it is considered necessary that provision or exceeding their duties it is considered necessary that provision should be m*de for the erasure from the register
midwife who has gravely miscondueted herself.

"Title of registered midwife.-The illegal assumption of this title should be a punishable offence."

23 It will be noted that these " suggestions" differ in some respects from th' se handed in on a previous occasion (see Appendix III.), when a deputation from the societs waited upon Mr. Stansfeld, the principal differences being (1) that the Obstetrical Society of London no longer suggested that it should itself undertake the examination, licensing,
and registration of midwives, but expressed the opinion that these and registration of midwives, but expressed the opinion that these duties would be best accomplished by a board especially formed for the
purpose; and (2) that nothing is said in this later document as to supervision or annual licensing.
APPENDIX V.

Table showing Result of Obstetrical Society's Examination for each year since its institution in 187\%. (From the Transactions of the Obstetrical Society, Vol. XLVII. for 1905, p. 80, with additions.)

\begin{tabular}{|c|c|c|c|c|c|c|c|}
\hline \multicolumn{4}{|c|}{ Year. } & \multirow{2}{*}{$\begin{array}{c}\begin{array}{c}\text { Candi- } \\
\text { dates. }\end{array} \\
8\end{array}$} & \multirow{2}{*}{ Passed. } & \multirow{2}{*}{ Failed. } & \multirow{2}{*}{ Absent. } \\
\hline 1872 & $\ldots \quad \ldots$ & $\quad \ldots$ & $\ldots$ & & & & \\
\hline 1873 & $\begin{array}{ll}\cdots & \ldots\end{array}$ & $\ldots$ & $\ldots$ & 12 & 11 & 1 & - \\
\hline 1874 & $\ldots \quad \ldots$ & $\ldots$ & $\ldots$ & 4 & 4 & 0 & - \\
\hline 1875 & $\ldots \quad \ldots$ & ... & $\ldots$ & 3 & 2 & 1 & - \\
\hline 1876 & $\begin{array}{ll}\ldots & \ldots\end{array}$ & $\ldots$ & $\ldots$ & 4 & 3 & 1 & - \\
\hline 1877 & $\begin{array}{lll}\ldots & \ldots\end{array}$ & $\ldots$ & $\ldots$ & 4 & 4 & 0 & - \\
\hline 1878 & $\begin{array}{ll}\ldots & \ldots\end{array}$ & $\ldots$ & $\ldots$ & 6 & 5 & 1 & - \\
\hline 1879 & ... $\quad \ldots$ & $\ldots$ & $\ldots$ & 13 & 12 & 1 & - \\
\hline 1880 & $\cdots \quad \ldots$ & $\ldots$ & $\cdots$ & 36 & 34 & 2 & - \\
\hline 1881 & $\ldots \quad \ldots$ & $\ldots$ & $\ldots$ & 30 & 27 & 3 & - \\
\hline 1882 & . $\quad \ldots$ & $\ldots$ & $\ldots$ & 42 & 37 & 5 & - \\
\hline 1883 & . $\quad \ldots$ & $\ldots$ & $\ldots$ & 67 & 53 & 11 & - \\
\hline 1884 & . $\quad \ldots$ & $\ldots$ & $\cdots$ & 63 & 49 & 14 & - \\
\hline 1885 & . $\quad \ldots$ & $\ldots$ & $\ldots$ & 82 & 68 & 14 & - \\
\hline 1886 & • $\quad \ldots$ & $\ldots$ & $\ldots$ & 102 & 80 & 22 & - \\
\hline 1887 & • $\quad \therefore$ & $\ldots$ & $\ldots$ & 127 & 96 & 29 & 2. \\
\hline 1888 & . $\quad \ldots$ & $\ldots$ & $\ldots$ & 153 & 127 & 22 & 4 \\
\hline 1889 & . $\quad \ldots$ & ... & $\ldots$ & 170 & 143 & 25 & 2 \\
\hline 1890 & . $\quad \ldots$ & $\ldots$ & $\ldots$ & 207 & 159 & 43 & 5 \\
\hline 1891 & - $\quad \ldots$ & $\ldots$ & $\ldots$ & 258 & 204 & 52 & 2 \\
\hline 1892 & - $\quad \cdots$ & $\ldots$ & $\ldots$ & 289 & 252 & 34 & 3 \\
\hline 1893 & . $\quad \cdots$ & $\ldots$ & $\cdots$ & 339 & 296 & 40 & 3 \\
\hline 1894 & . $\quad \cdots$ & $\ldots$ & $\ldots$ & 432 & 390 & 40 & 2 \\
\hline 1895 & $\cdot \quad \cdots$ & $\ldots$ & $\ldots$ & 467 & 420 & 33 & 14. \\
\hline 1896 & . $\cdots$ & $\ldots$ & $\ldots$ & 511 & 461 & 40 & 10 \\
\hline 1897 & . $\quad \cdots$ & $\ldots$ & $\ldots$ & 590 & 523 & 49 & 18 \\
\hline 1898 & $\cdot \quad \cdots$ & $\ldots$ & $\ldots$ & 688 & 604 & 75 & 9 \\
\hline 1899 & . $\quad \cdots$ & $\ldots$ & $\cdots$ & 842 & 705 & 119 & $18:$ \\
\hline 1900 & - $\quad \cdots$ & $\ldots$ & $\ldots$ & 925 & 754 & 155 & 16 \\
\hline 1901 & . $\quad \ldots$ & $\ldots$ & $\ldots$ & 980 & 769 & 195 & 16 \\
\hline 1902 & $\cdots$ & $\ldots$ & $\ldots$ & 1274 & 996 & 260 & 18 \\
\hline 1903 & . $\quad \cdots$ & $\ldots$ & $\ldots$ & $1 E 45$ & 1221 & 298 & 26 \\
\hline 1904 & 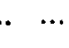 & $\ldots$ & $\cdots$ & 1861 & 1507 & 331 & 23 \\
\hline $\begin{array}{c}1905 \\
\text { onl }\end{array}$ & $\begin{array}{r}\text { exan } \\
. \quad \cdots \\
\end{array}$ & $\begin{array}{c}\text { ninat } \\
\cdot \quad \cdots\end{array}$ & $\left.\begin{array}{c}\text { ion } \\
\ldots\end{array}\right\}$ & 674 & 558 & 113 & 3 \\
\hline & $\ldots$ & . $\quad \ldots$ & $\cdots$ & 12805 & 10580 & 2031 & - \\
\hline
\end{tabular}

\section{THE RÔLE OF THE BLOOD PLASMA IN DISEASE.}

By Harry Campbell, M.D., B.S. Lond., F.R.C.P. Lond, PHYSICIAN TO THE NORTH-WEST LONDON HOSPITAI AND TO THE HOSPITAX FOR DISEASHS OF THE NERTOUS SYSTEM, WELBECK-STREET.

III. ${ }^{1}$

Influence of Plasma on Stiructure.

WE have seen that the environing plasma affects the function of the cell in an infinite variety of ways. We havenow to consider how far this same influence can affect itsstructure. That the plasma is capable of producing profound structural alterations is shown by the action of such substances as alcohol, arsenic, and phosphorus, all of which operate through its medium; and we are beginning to see that certain hormones, such as those Jielded by the ovaries, testes, thyroid and adrenal glands, exert a remarkable influence on growth and development.

Function and structure proceed pari passu.-The environmental influences brought to bear upon the cell have, in fact, a potent influence over its structure, far more potent than is generally thought, for whatever modifies function modifies structure at the same time; whenever, i.e., a new form of functional activity is induced in a cell, whether through its

1 Articles I. and II. were published in The LAavCET of Feb. 2nd (p. 313) and 9th (p. 375), 1907, respectively. 